await resolution of the haematoma. In addition, it had been decided to recommence anticoagulant treatment after operation in order to prevent thrombus formation on the mitral valve prosthesis.

The management of a sudden serious abdominal emergency in patients on anticoagulant treatment may tax the most experienced clinician, but an intraabdominal or retroperitoneal haemorrhage should be considered to be the most likely diagnosis. Provided the patient's condition improves rapidly after discontinuing anticoagulant therapy, conservative management with intravenous fluids and nasogastric aspiration is advisable, but laparotomy is essential if another diagnosis cannot confidently be excluded. Careful examination of the gas shadows on plain abdominal X-rays may reveal the 'picket-fence' and 'thick-bowel' signs which are diagnostic of an intramural haemorrhage.

\section{Acknowledgment}

I wish to thank Dr P. Fleming, F.R.C.P., for permission to publish this case.

\section{References}

BeAmish, R.E. \& MCCREATH, N.D. (1961) Intestinal obstruction complicating anticoagulant therapy. Lancet, ii, 390.

Berman, H. \& Mainella, F.S. (1952) Toxic results of anticoagulant therapy. New York Journal of Medicine, 52, 725.
CAIRD, D.M. \& ElLIS, H. (1958) Intra-mural haematoma of duodenum. British Journal of Surgery, 45, 389.

Gabriele, O.F. \& CoNTE, M. (1964) Spontaneous intramural haemorrhage of the colon. Archives of Surgery, 89, 522.

Gilbert, A.E. \& Jorgensen, M.C. (1960) Small bowel obstruction due to hemorrhage secondary to anticoagulant therapy. American Journal of Surgery, 99, 945.

GoldFARB, W.B. (1965) Coumarin-induced intestinal obstruction. Annals of Surgery, 161, 27.

Hafner, C.D., Crawley, J.J., Krauser, R.J. \& Strasser, E.S. (1962) Anticoagulant ileus. Journal of the American Medical Association, 182, 947.

Herbert, D.C. (1968) Anticoagulant therapy and the acute abdomen. British Journal of Surgery, 55, 353.

JAQUES, L.B. (1959) Dicoumarol drugs and the problem of haemorrhage. Canadian Medical Association Journal, 81, 848.

Khilnani, M.T., Marshak, R.H., Eliasoph, J. \& Wolf, B.S. (1964) Intramural intestinal haemorrhage. American Journal of Roentgenology, 92, 1061.

RAINE, J.W.E. (1963) Abdominal complications of anticoagulant therapy. New Zealand Medical Journal, 62, 85.

Sears, A.D., Hawkins, J., Kilgore, B.B. \& Miller, J.E. (1964) Plain roentgenographic findings in drug induced intramural hematoma of the small bowel. American Journal of Roentgenology, 91, 808.

Spencer, R.J., Bateman, J. \& Horn, P. (1957) Intramural hematoma of the intestine: a rare cause of intestinal obstruction. Surgery St Louis, 41, 794.

Wiot, J.F., Weinstein, A.S. \& Felson, B. (1961) Duodenal hematoma induced by coumarin. American Journal of Roentgenology, 86, 70.

\title{
Primary biliary cirrhosis in brothers
}

\begin{abstract}
R. Bown
M.B., B.S., M.R.C.P.

Summary

This is the first report of two brothers who demonstrated the classical clinical course, histology, biochemistry and auto-antibodies of primary biliary cirrhosis. Both also exhibited an associated keratoconjunctivitis sicca and, in one, renal tubular acidosis resulted in severe systemic acidosis after lactulose therapy and with a subsequent intraperitoneal variceal rupture.

Screening of the relatives recalled a high incidence of 'auto-immune' disease and auto-antibodies.
\end{abstract}

\author{
M. L. Clark \\ M.D., M.R.C.P.
}

D. DONIACH
M.D., F.R.C.P.
THE recognition that a familial factor may be operative in the genesis of primary biliary disease follows the report (Walker et al., 1972) of two sisters who presented with symptoms of biliary obstruction, the one with pruritus and the other with biliary colic and jaundice. Both of these patients had high titres of antimitochondrial antibodies as is seen in primary biliary cirrhosis (Doniach et al., 1966), but neither exhibited the biochemical findings (Foulk and Baggenstoss, 1969), the typical liver histology (Scheuer, 1968) or the insidious deterioration characteristic of that disease. The remainder of the family of these patients demonstrated a very high incidence of antimitochondrial and antithyroid antibodies although without apparent overt disease.

In a later study Chohan (1973) reported twin sisters with undoubted primary biliary cirrhosis. 
We present in this study the first report of two brothers with primary biliary cirrhosis who incidentally also demonstrated multi-system involvement of a presumed immune nature. In addition, the sera of twelve of their fourteen surviving relatives were screened for autoantibodies.

\section{Case 1}

In December 1963 a 58-year-old man was admitted to hospital for investigation of an 8-year history of dyspepsia.

Physical examination was unremarkable but investigation revealed a raised alkaline phosphatase of $63 \mathrm{~K} . \mathrm{A} . \mathrm{u} / 100 \mathrm{ml}$, although all other liver function tests including the bilirubin and albumin were normal. A barium meal showed an abnormality of the duodenal loop compatible with a carcinoma of the pancreas. At a subsequent laparotomy the pancreas, stomach and duodenum were normal, but the liver was found to be cirrhotic. A wedge biopsy of this showed the histological appearances of early primary biliary cirrhosis with ductular proliferation, intense lymphocytic infiltration and granuloma formation.

After recovery from the operation he remained well until December 1969 when he had a severe haematemesis following aspirin ingestion. He was readmitted and on re-examination complained of itching and was by now mentally slow, hoarse, and showed palmar erythema with occasional spider naevi. The liver and spleen were both easily palpable. Investigation revealed a haemoglobin of $6 \mathrm{~g} / 100 \mathrm{ml}$; bilirubin $1.1 \mathrm{mg} / 100 \mathrm{ml}$; alkaline phosphatase 100
K.A. u/100 ml; alanine aminotransferase 85 i.u./l; albumin $2.8 \mathrm{~g} / 100 \mathrm{ml}$; a bromsulphthalein retention of $34 \%$ at $45 \mathrm{~min}$. An electroencephalogram and psychometric testing were compatible with hepatic encephalopathy whilst a barium swallow showed gross oesophageal varices. The results of the antibody screening are shown in Fig. 1. A percutaneous liver biopsy showed advanced primary biliary cirrhosis. In view of the hoarse voice indirect laryngoscopy was performed and this showed a granular appearance of the vocal cords.

After consideration of the poor prognosis of latestage primary biliary cirrhosis the haematemesis was managed conservatively. Whilst being followed up as an outpatient, however, in spite of progressive reduction of his protein intake and therapy with oral lactulose, his encephalopathy became more severe.

By March 1970 he was in hepatic pre-coma and on readmission was again noted to be hoarse but, in addition, complained of dry eyes and a dry mouth. Investigation showed the Schirmer's type 1 test, which is a test of lacrimal gland function, to be only $1 \mathrm{~mm}$ in $5 \mathrm{~min}$ in the right eye with a corresponding value of $6 \mathrm{~mm}$ in $5 \mathrm{~min}$ for the left eye (normal $>10$ $\mathrm{mm}$ in $5 \mathrm{~min}$ ) and both cornea and conjunctiva stained with rose bengal. The salivary secretion (Golding et al., 1970b) was $3 \mathrm{ml}$ in $10 \mathrm{~min}$ (normal $>10 \mathrm{ml}$ in $10 \mathrm{~min})$; the blood urea was $30 \mathrm{mg} / 100$ $\mathrm{ml}$; serum potassium was initially $2.4 \mathrm{mEq} / \mathrm{l}$ but rose on supplements to $3.6 \mathrm{mEq} / 1$; serum bicarbonate $14 \mathrm{mEq} / 1 ; \mathrm{pH}$ of the urine was 6.45 with a simultaneous plasma $\mathrm{pH}$ of $7 \cdot 29$; creatinine clearance 35

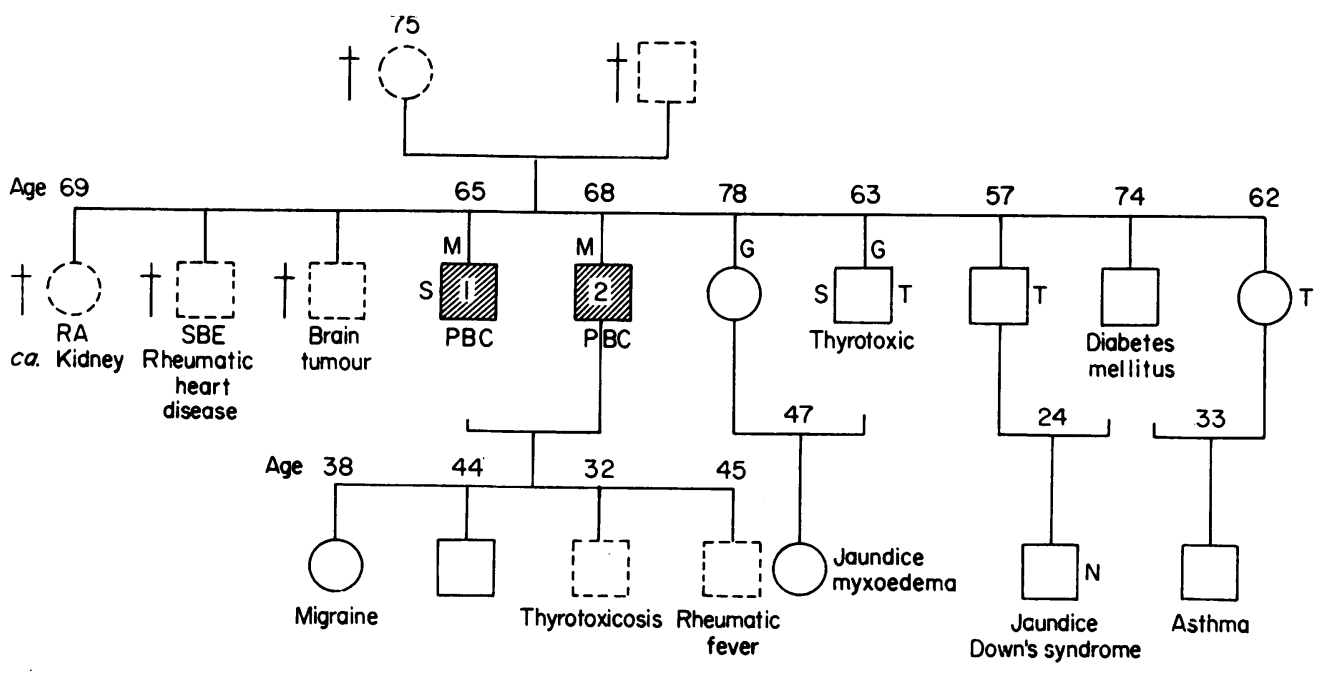

FIG. 1. Family tree of brothers with primary biliary cirrhosis showing incidence of other diseases and presence of serum antibodies. $\mathscr{W}$, liver disease; $N$, nuclear (ANA) antibodies; $\mathrm{S}$, smooth muscle antibodies; $\mathbf{M}$, mitochondrial antibodies; $T$, thyroid antibodies; G, gastric parietal cell antibodies. 
$\mathrm{ml} / \mathrm{min}$; MSU, sterile with no abnormality on centrifugation.

These investigations showed that in addition to his hepatic disease he also had 'keratoconjunctivitis sicca' and a renal tubular acidosis which persisted even after the serum potassium had returned to normal. The cause for the mental deterioration appeared to be the result of constipation and hypokalaemia and after correction of these with enemata and potassium replacements he was maintained once again on lactulose as an inpatient. The serum bicarbonate, however, continued to fall (Fig. 2) from $17 \mathrm{mEq} / \mathrm{l}$ to between 7 and $9 \mathrm{mEq} / \mathrm{l}$ until the lactulose was replaced by oral neomycin. Two weeks after admission he suddenly became hypotensive although without overt blood loss and he then lost consciousness. As the abdomen showed an acute increase in girth a peritoneal tap was performed which revealed intra-peritoneal bleeding, presumably from a ruptured varix. At this time the serum bicarbonate fell to only $3 \mathrm{mEq} / \mathrm{l}$. He was therefore treated with blood transfusions and intravenous bicarbonate therapy and gradually recovered consciousness. Convalescence was prolonged and later that year his hepatic function further deteriorated. He finally died in hepatic coma in January 1971.

Post mortem confirmed a late stage primary biliary cirrhosis with oesophageal varices. The histology of macroscopically normal salivary glands showed a mild focal lobular atrophy associated with widespread lymphocytic infiltration particularly around the small ducts, some of which also showed evidence of epithelial degeneration. The kidneys showed no gross change but histology revealed mild ischaemic atrophy and scarring at the periphery of the cortex. In addition, scattered throughout the cortex were focal interstitial aggregates of lymphocytes. There were no features suggestive of pyelonephritis.

\section{Case 2}

The 58-year-old brother of Case 1 presented to hospital in 1961 with hoarseness. Direct laryngoscopy showed hyperaemia and swelling of the vocal cords whilst a biopsy was reported as showing chronic inflammatory changes.

In April 1968 he was readmitted to hospital with angina, nausea, and upper abdominal pain radiating through to the back. There was no previous history of hepatitis or excessive alcoholic intake. On examination he had the signs of mild aortic stenosis and was minimally jaundiced. The liver and spleen were not palpable and there were no other stigmata of liver disease. Investigation showed normal haematology but the liver function tests were abnormal-serum bilirubin $1.5 \mathrm{mg} / 100 \mathrm{ml}$; alanine aminotransferase 61 i.u./1; serum cholesterol 232 $\mathrm{mg} / 100 \mathrm{ml}$; alkaline phosphatase $28 \mathrm{~K}$.A. u. Plain abdominal radiography showed an opacity overlying

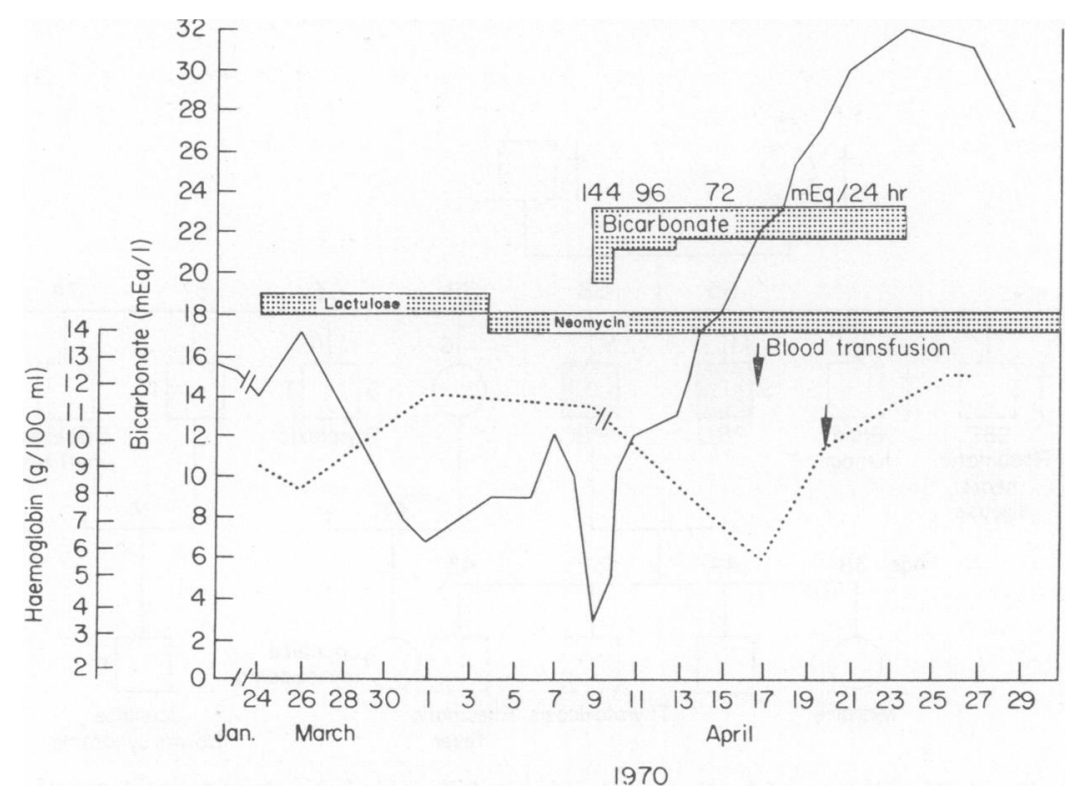

FIG. 2. Flow chart of patient showing progress of haemoglobin (dotted line) and serum bicarbonate (solid line) on treatment with neomycin, lactulose and bicarbonate. 
the right eleventh rib but a cholecystogram showed good gall bladder concentration with free flow in the cystic and common bile ducts.

After bed rest his symptoms resolved and he remained well until October 1970 when he was readmitted following a syncopal attack. On examination he was by now frankly jaundiced with a palpable liver to $4 \mathrm{~cm}$. The stools were pale and the urine dark.

Investigations showed serum bilirubin $5.8 \mathrm{mg} / 100$ $\mathrm{ml}$; alkaline phosphatase $28 \mathrm{~K} . \mathrm{A} . \mathrm{u} / 100 \mathrm{ml}$; alanine aminotransferase 128 i.u./1; total serum proteins $6 \cdot 2$ $\mathrm{g} / 100 \mathrm{ml}$, albumin $2.4 \mathrm{~g} / 100 \mathrm{ml}$. Plain abdominal radiography again showed a calcified opacity in the region of the gall bladder, but intravenous cholangiography did not opacify the gall bladder. The results of antibody screening are shown in Fig. 1.

On the 7 December 1970 a percutaneous cholangiogram was attempted but bile could not be aspirated and the investigation was abandoned. Two weeks later a laparotomy was performed which revealed a cirrhotic, shrunken liver with a solitary large gallstone present in the gall bladder. A cholecystostomy was performed for removal of the gallstone and a liver biopsy taken which showed an established cirrhosis of a monolobular pattern. Although there were no granulomatous lesions the pattern of the cirrhosis, the dearth of small bile ducts and the presence of dense focal aggregates of lymphocytes in the portal connective tissue established the diagnosis of primary biliary cirrhosis. Postoperatively his liver function gradually failed with episodes of hepatic coma and ascites, but on occasions, when conscious, he complain of dry, gritty eyes and was thought clinically also to have keratoconjunctivitis sicca. In spite of all treatment he died in March 1971. Post mortem was not performed.

\section{Patients and relatives}

Seven survivors of the siblings, and five of their seven offspring have been investigated for autoantibodies, and their past medical history noted (Fig. 1).

\section{Serological methods}

Immunofluorescence was done by the standard sandwich technique with anti- $\gamma$-fluorescine isothiocyanate conjugates, on composite blocks of human thyroid, stomach and kidney. Rat liver and kidney were included for smooth muscle and 'reticulin' antibodies, all sera being screened at $1: 10$. Positive reactions were then titrated to the end point on appropriate organs. Complement fixation (CFT) was done using two mean haemolysing doses of complement with a lyophilized preparation of purified rat liver mitochondria. The tanned red cell (TRC) test for thyroglobulin antibodies was done with Burroughs Wellcome cells in microtitre trays.
The sera were screened for Australian antigen (HAA) and for Milan antigen (Del Prete et al., 1972) by double diffusion precipitin tests performed by $\operatorname{Dr} \mathrm{S}$. Del Prete, Milan.

\section{Family history (Fig. 1)}

Both parents had died, the mother at $\mathbf{7 5}$ following a 'collapse' and the father of bronchitis and cor pulmonale. Two brothers of the propositi had previously died, one of rheumatic heart disease and bacterial endocarditis, and the other with a brain 'tumour'. One sister who suffered from rheumatoid arthritis had died from a renal carcinoma. Of the seven other siblings, the two propositi died from hepatic failure due to primary biliary cirrhosis, and of the other brothers one of these, although apparently healthy, exhibited a low titre of thyroid antibodies, another has now developed diabetes mellitus, and the third had been treated for thyrotoxicosis whilst his serum contained low-titre thyroid, gastric parietal cell, and smooth muscle antibodies. The two surviving sisters were healthy but both showed antibody activity, one to thyroid in high titre and the other to gastric parietal cells in low titre.

Case 1 had not married until late in life and had no children. Case 2 had four children, the only daughter and one son being healthy. Two sons were not available for examination but one was said to be thyrotoxic and the other had suffered from rheumatic fever.

In the three remaining offspring, one was born with Down's syndrome, exhibited antinuclear antibodies, and had been jaundiced at birth and again at the age of 22; one was healthy but suffered from bronchial asthma and the other had been myxoedematous since the age of 12 and had been jaundiced 9 years previously.

\section{Virus hepatitis associated antigens}

The serum of Case 1, taken in the terminal stages after multiple blood transfusions, was positive for Australia antigen, but negative for Milan antigen. Case 2 could not be tested. The relatives gave negative results, both for Australia antigen and Milan antigen.

\section{Discussion}

This appears to be the first time primary biliary cirrhosis has been reported in brothers. In two sisters reported by Walker et al. (1972), although both showed high titres of antimitochondrial antibodies, the biochemical picture and benign clinical course was more in keeping with a diagnosis of chronic persistent hepatitis (De Groote et al., 1968). However, the histology in both sisters showed piecemeal necrosis of liver cells with distortion of limiting cellplates, a condition usually associated with the more 
malignant chronic aggressive hepatitis (De Groote et al., 1968).

The first undoubted case of primary biliary cirrhosis occurring in siblings was described by Chohan (1973) in twin sisters but no follow up was reported. Previous cases as cited by Chohan (Da Silva and De Brito, 1966; Kuhn, 1963) seem, on review, to have been examples of 'benign, recurrent intrahepatic cholestasis', which may well result from exogenous factors (Scheur et al., 1964).

Both the sisters as described by Walker et al. (1972) and the brothers of the present study demonstrated other auto-immune phenomena. Both the sisters were discovered to have an occult thyroiditis, although this had not apparently interfered with the functions of the glands either clinically or biochemically, and subsequently one of these sisters has now developed bilateral parotid swellings suggestive of chronic sialoadenitis. Similarly, in these present two brothers, one had proved keratoconjunctivitis sicca with xerostomia whilst the other was suspected of having this condition following complaints of dry, gritty eyes during his final admission. This sicca syndrome is now known to be present in as many as $73 \%$ of cases with primary biliary cirrhosis (Golding et al., 1970b) and is characterized by atrophy of the acini of the salivary and lacrimal glands associated with lymphocytic infiltration. The hoarseness which both men exhibited has long been known to be due to a similar degeneration of the mucosal glands of the larynx but although previously recognized to occur in Sjögren's syndrome (sicca syndrome) due to other causes (Gougerot, 1926) it has not previously been reported in patients with liver disease.

Renal tubular acidosis is also frequently found in association with primary biliary cirrhosis (Golding and Mason, 1971) and Case 1 presented an unusual problem in clinical management.

Following the administration of lactulose, the serum bicarbonate dropped quite markedly but when the lactulose was replaced by neomycin this fall was reversed. Th is increase in systemic acidosis may be explained on the basis of subsequent observations that lactulose administration is followed by acidification of the colon and particularly the caecum, with a corresponding increase in bicarbonate secretion by the mucosa (Bown et al., 1971). This is usually insufficient to affect the serum bicarbonate level in normal subjects but with a coincidental renal inability to secrete an acid urine this additional acid load may produce an overt systemic acidosis.

Furthermore, during the subsequent hypotensive episode when renal perfusion was minimal the serum bicarbonate fell to extremely low levels with the development of hepatic coma. In spite of the presence of large quantities of intraperitoneal blood, the coma quickly resolved with blood transfusions and intra- venous bicarbonate therapy and it therefore seems likely that this marked acidosis played an important part in the precipitation of the hepatic coma. The intraperitoneal haemorrhage which was the cause of the hypotensive episode is surprisingly rare in portal hypertension, with only one case previously reported from a ruptured varix (Ross, 1970).

Screening of this present family revealed three relatives with overt thyroid disease and a sister who, although apparently euthyroid, showed high titres of anti-thyroid antibody. The majority of the rest of the family either suffered from diseases in which a disturbed immunological system may play an aetiological role or exhibited auto-antibodies. In the previous family study (Walker et al., 1972) although there was no overt autoimmune disease, two brothers showed a moderate titre of antimitochondrial antibodies whilst half the family had antithyroid activity as demonstrated serologically. It seems likely, therefore, that not only do patients with so-called 'immune liver disease', and particularly primary biliary cirrhosis have associated multi-system autoimmune disease (Golding, Bown and Stuart-Mason, 1970a) but also that there is a much higher incidence of these conditions in their relatives. This is borne out by two recent family studies (Feizi et al., 1972; Galbraith et al., 1973) which have both shown a 7\% incidence of mitochondrial antibodies in relatives of PBC patients, as compared with $0.7 \%$ in normal subjects.

\section{Acknowledgments}

We would like to thank Dr A. M. Dawson for permission to study Case 1 and for his helpful comments in preparation of this paper. R.B. was supported by the Board of Governors of St Bartholomew's Hospital.

\section{References}

Bown, R.L., Sladen, G.E., Clark, M.L. \& Dawson, A.M. (1971) The production and transport of ammonia in the human colon. Gut, 12, 863.

Chohan, M.R. (1973) Primary biliary cirrhosis in twin sisters. Gut, 14, 213.

Da Silva, L.C. \& De Brito, T. (1966) Benign recurrent intrahepatic cholestasis in two brothers. Annals of Internal Medicine, 65, 330.

De Groote, J., Desmet, V.J., Gedick, P., Korb, G., PepPer, H., Poulsen, H., Scheuer, P.J., Schmid, M., Thaler, H., UEHLINGER, E. \& WePleR, W. (1968) A classification of chronic hepatitis. Lancet, ii, 626.

Del Prete, S., Costantino, D., Doglia, M., Fabiani, M.P. \& Borin, R. (1972) Epidemic hepatitis-associated antigen. Canadian Medical Association Journal, 106, 493.

DoniaCh, D., RoITT, I.M., WALKer, J.G. \& Sherlock, S. (1966) Tissue antibodies in primary biliary cirrhosis, chronic active hepatitis, cryptogenic cirrhosis and other liver diseases, and their clinical implications. Clinical and Experimental Immunology, 1, 237.

Feizi, T., Naccarato, R., Sherlock, S. \& Doniach, D. (1972) Mitochondrial and other tissue antibodies in relatives of patients with primary biliary cirrhosis. Clinical and Experimental Immunology, 10, 609. 
Foulk, W.T. \& Baggenstoss, A.H. (1969) In: Diseases of the Liver (Ed. by L. Schiff), p. 245. J. B. Lippincott: Philadelphia.

Galbraith, R.M., Smith, G.M., McKenzie, R.M., DoniACH, D., Williams, R. \& Tee, D.S. (1974) High prevalence of seroimmunologic abnormalities in relatives of patients with active chronic hepatitis or primary biliary cirrhosis. New England Journal of Medicine, 290, 63.

Golding, P.L., Bown, R. \& Stuart-Mason, A. (1970a) Studies on multi-system involvement in active chronic hepatitis and primary biliary cirrhosis. In: Immunology of the Liver (Ed. by M. Smith and R. Williams), p. 194. Heinemann: London.

Golding, P.L., Bown, R., Mason, A.M.S. \& Taylor, E. (1970b) 'Sicca Complex' in liver disease. British Medical Journal, iv, 340.

Golding, P.L. \& MASON, A.M.S. (1971) Renal tubular acidosis and auto-immune liver disease. Gut, 12, 153.
GoUgEROT, H. (1926) Insuffisance progressive et atrophie des glandes salivaires et muqueuses de la bouche, des conjontives (et parois des muqueuses nasales, laryngée, vulvaire), sécheresse de la bouche, des conjonctives, etc. Bulletin Medical (Paris), 40, 360.

KUHN, H.A. (1963) Intrahepatic cholestasis in two brothers. German Medicine Monthly, 8, 185.

Ross, A.P. (1970) Portal hypertension presenting with haemoperitoneum. British Medical Journal, i, 544.

SCHEUER, P.J. (1968) In: Liver Biopsy Interpretation, p. 22. Baillière, Tindall and Cassell: London.

Scheuer, P.J., Williams, R., Hill, K.R. \& Sherlock, S. (1964) Jdiopathic recurrent hyperbilirubinaemia. Tijdschrift voor Gastro-enterologie, $7 \mathrm{~b}, 173$.

Walker, J.G., Bates, D., Doniach, D., Ball, P.A.J. \& SHERLOCK, S. (1972) Chronic liver disease and mitochondrial antibodies: a family study. British Medical Journal, i, 146.

\title{
Vick vapour rub intoxication
}

\author{
J. M. DUCKHAM \\ B.Sc., M.B., B.S., M.R.C.P. \\ H. A. LEE \\ B.Sc., M.B., B.S., M.R.C.P.
}

St Mary's General Hospital, Portsmouth, Hampshire

\section{Summary}

So far as we are aware there has been no previous report of Vick vapour rub intoxication presenting as iron deficiency anaemia with minimal liver functional impairment. We present this case for its interest and to illustrate the rewards of a routine and detailed drugtaking history.

\section{Case report}

A 66-year-old housewife was referred as a case of anaemia which had failed to respond to several courses of oral iron over a 2-year period. Her complaints were of intermittent epigastric discomfort and flatulence occurring immediately after food and partially relieved by alkali mixtures. For 3 months she had noticed increasing abdominal distension.

She passed semi-formed orange-brown motions daily, and denied weight loss. She took analgesic tablets (Codis and Paracetamol), totalling at least 6/week over many years, for arthralgia affecting the ankles, knees and neck. In India as a child she had been given arsenic, 1 drop daily on alternate weeks over 12 months as prophylaxis against malaria infection.

On initial examination the abnormal findings were that she was pale with typical 'rain drop' pigmentation of the face and neck as a result of arsenic therapy. The abdomen was symmetrically enlarged with a smooth, firm, liver edge palpable 2 fingerbreadths below the costal margin. Rectal examination revealed orange-brown faeces.

Her haemoglobin was $7.8 \mathrm{~g} / 100 \mathrm{ml}$, MCV 75 , MCHC 29.2 and a film showed anisocytosis and anisochromasia compatible with iron deficiency; the ESR was $22 \mathrm{~mm} / \mathrm{hr}$. The serum alkaline phosphatase was raised to 18 K.A. u but all other serum biochemical tests were normal. Urine analysis was normal. Chest X-ray and barium meal examinations showed no evidence of neoplasm.

On admission for further investigations she admitted eating at least one bottle ( $38 \mathrm{~g}$ ) of Vick vapour rub every day for 2 years, for relief of her smoker's cough.

A repeat blood film showed toxic granulation of neutrophil leucocytes. A 3-day faecal fat analysis on a ward diet gave a total of $\mathbf{9} \mathbf{g}$ of fat. She had weakly positive occult blood tests on three occasions. Liver scan confirmed hepatomegaly with a fairly extensive patchy uptake of indium hydroxide $113 \mathrm{~m} /$ citric acid colloid. Liver biopsy was normal apart from mild fatty infiltration.

Withdrawal of Vick vapour rub and oral iron supplementation resulted in the rapid disappearance of toxic granulation, and a rise in haemoglo bin to $13 \mathrm{~g} / 100 \mathrm{ml}$ with a fall in serum alkaline phosphatase to 12 King-Armstrong $u$ after 3 months. At this time 